ISSN1027-5495. Functional Materials, 24, No.4 (2017), p. 692-698

doi:https://doi.org/10.15407/fm24.04.692

(C) 2017 - STC “Institute for Single Crystals"

\title{
Research of the properties of renewable energy sources with battery electrode from new materials
}

\author{
Song xueying ${ }^{1,2}$, Tan zhongfu', Li huanhuan ${ }^{1}$ \\ ${ }^{1}$ School of Economics and Management, North China Electric Power \\ University, Beijing 102206, China \\ ${ }^{2}$ School of Economics and Management, Inner Mongolia University of \\ Science \& Technology, Baotou 014010, China
}

Received September 15,2017

\begin{abstract}
A new type of material is proposed for the electrodes of a storage battery with a high energy density and stable characteristics. The structure and electrochemical properties of the new material are analyzed under two different methods of production. The system of connection to the power system is analyzed, and the energy-saving system for optimization of the output power of renewable energy. The economic benefit of the proposed battery is analyzed. The results show that the energy storage system of the new anode material for the battery is technically and economically justified and can be used to solve a complex energy consumption problem. Keywords: energy storage, battery cathode material, materials analysis, mathematics analysis.
\end{abstract}

\begin{abstract}
Предлагается новый тип материала электродов для аккумуляторной батареи с высокой плотностью энергии и стабильными характеристиками. Исследуется структура и электрохимические свойства нового материала при двух разных способах производства. Анализируется система подключения к энергосистеме и система энергосбережения для оптимизации выходной мощности возобновляемой энергии. Рассматривается экономическая выгода предлагаемого аккумулятора. Результаты показывают, что система хранения энергии нового анодного материала для батареи технически и экономически оправдана и может быть использована для решения комплексной проблемы потребления энергии.
\end{abstract}

Дослідження властивостей поновлюваних джерел енергії з електродом батареї з нових матеріалів. Song xueying, Tan zhongfu, Li huanhuan. Пропонуеться новий тип матеріалу електродів акумуляторної батареї з високою щільністю енергії і стабільними характеристиками. Досліджуеться структура і електрохімічні властивості нового матеріалу при двох різних способах виробництва. Аналізуеться система підключення до енергосистеми і система енергозбереження для оптимізації вихідної потужності відновлюваної енергії. Розглядається економічна вигода пропонованого акумулятора. Результати показують, що система зберігання енергії нового анодного матеріалу для батареї технічно і економічно виправданаіможебутивикористанадлявирішеннякомплексноїпроблемиспоживанняенергії.

\section{Introduction}

With the depletion of fossil fuels and the increasing pollution of the environment, renewable energy has attracted wide attention from all over the world. As a clean, efficient renew- able energy, wind power has a broad development and market prospects space in China. On the one hand, wind power and solar photovoltaic power output has random, volatility and intermittent characteristics. Wind power and 
solar PV grid connection require the power grid provide enough backup service. On the other hand, the wind and solar resource areas are far from load centres. Long - distance renewable energy transmission has great cost and technical problems. Therefore, the configuration of energy storage system in the power grid is an important means to protect the power grid safety and stable operation and reduce abandoned renewable power.

Energy storage methods are divided into four categories[1], namely, mechanical energy storage (Pumping energy storage, flywheel energy storage, and compressed air storage and so on), chemical energy storage(Lead-acid batteries, nickel batteries, lithium batteries, sodium and sulfur batteries, zinc empty batteries, super capacitors, etc.), electromagnetic energy storage(superconducting energy storage), phase change energy storage(Ice storage and heat storage). Performance comparison of different energy storage systems is list in table 1 . Wherein, super capacitor energy storage [2], flywheel energy storage, superconducting magnetic energy storage to stabilize the power fluctuations within the grid and provide shortterm power support for the target. Compressed air storage and pumped storage power station has large capacity and long-term scale energy storage characteristics [3], but because of geographical conditions and efficiency constraints, development and utilization are subject to great restrictions.

Energy storage batteries have a long development history [4-7]. Mature electrochemical energy storage technologies such as lead acid, nickel, and lithium have been used in large quantities. Battery storage technology in the distributed energy storage and large-scale power plant energy storage industry conditions has become increasingly mature. The US EPRI energy storage project research program carried out in the lithium-ion battery for distrib- uted energy storage research and development. In China, the National Power Grid and China Southern Power Grid also began to try to use high-power lithium-ion battery as the energy storage system power supply.

In this paper, the use of new battery anode material makes lithium-ion battery storage density to further this condition, the lithium-ion battery and super capacitor combined into energy storage system. The energy storage system will be excess solar energy or wind energy into electrical energy storage, electricity peak in the form of energy released to meet people's needs, reduce the thermal power unit start and stop, to promote the elimination of renewable energy.

\section{New energy storage battery anode material $\mathrm{LiNb}_{3} \mathrm{O}_{8}$}

Firstly, storage battery must meet the safety constraints and with high energy conversion efficiency. Then storage battery has higher specific energy and specific power density. And finally,cost,service life and environment-friendly factors should be considered. Energy-saving lithium-ion battery is different from the mature small lithium-ion battery and the development of power lithium-ion battery. It has the following characteristics:

- high energy density, the volume of energy density and mass energy density of up to 400Wh / L and 200Wh / Kg;

- high operating voltage. The average output voltage up to $3.6 \mathrm{~V}$, is cadmium, nickel-metal hydride batteries 3 times;

- self-discharge rate is low, less than $10 \%$ per month or less;

- good stability, lithium-ion battery in the non-use state, the storage almost no chemical reaction;

Table1. Performance comparison of different energy storage system

\begin{tabular}{|c|c|c|c|c|}
\hline parameter & accumulator & EDLC & SMES & FWES \\
\hline watt density(W/Kg) & $50-200$ & $7000-18000$ & 1000 & $180-1800$ \\
\hline energy density, Wh/Kg & $20-100$ & $1-10$ & $<1$ & $5-50$ \\
\hline efficiency, \% & $80-85$ & $>95$ & 90 & $90-95$ \\
\hline security & high & high & low & medium \\
\hline maintenance & few & less & many & more \\
\hline cost, p.u. & 1 & 8 & 20 & 4 \\
\hline
\end{tabular}




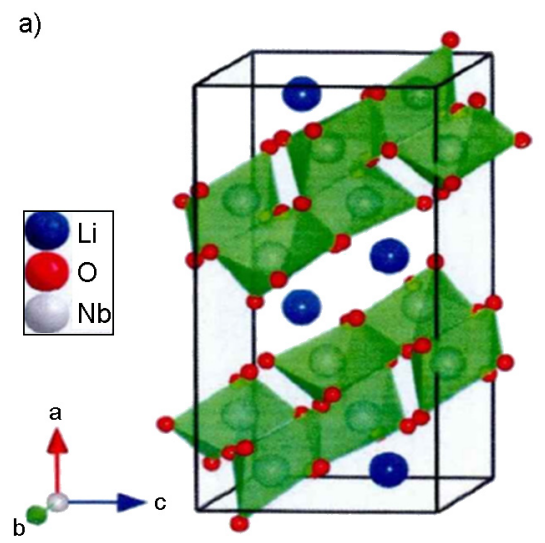

Fig. 1. Cell diagram of $\mathrm{LiNb}_{3} \mathrm{O}_{8}$

- Long cycle life; can be safe and fast charge; allow a wide working temperature range $-20-60^{\circ} \mathrm{C}$;

- no-memory effect;

- environmentally friendly, green battery, does not contain toxic heavy metals.

Currently, lithium-ion battery anode materials are mostly carbon materials, electrolytes in most of the solvents for the carbonic acid organic solvents. During the cycle, the electrode material forms a layer passivation film (SEI film). If the discharge cut-off voltage is set to $1 \mathrm{~V}$ or more, the generation of the SEI film can be avoided. So that it has a very excellent cycle performance and magnification performance, is a very promising anode material. But its theoretical capacity is only $175 \mathrm{mAh} / \mathrm{g}$ and the capacity cannot be further improved. In order to improve the energy density of the battery, new negative materials should be adopted.

2.1 Characteristics and working principle of energy storage battery cathode material $\mathrm{LiNb}_{3} \mathrm{O}_{8}$

$\mathrm{LiNb}_{3} \mathrm{O}_{8}$ has a monoclinic structure with a space group of P121 / a, four Li atoms, $32 \mathrm{O}$ atoms and $12 \mathrm{Nb}$ atoms form a unit. Its structure consists of twisted $\mathrm{Nb}-\mathrm{O}$ octahedral, Li atoms in the octahedral gap position, as shown in Fig. 1.

Lithium-ion battery from the positive, negative, electrolyte, diaphragm and current collector and other components. The process of charging and discharging is achieved by the insertion and removal of lithium ions in the positive and negative materials. When the lithium ion is separated from the positive electrode material, it moves from the diaphragm to the negative direction, and the electrons are removed from the positive electrode, migrated from the external circuit to the negative electrode, and an electron is obtained on the negative electrode and then converted into a layered structure In

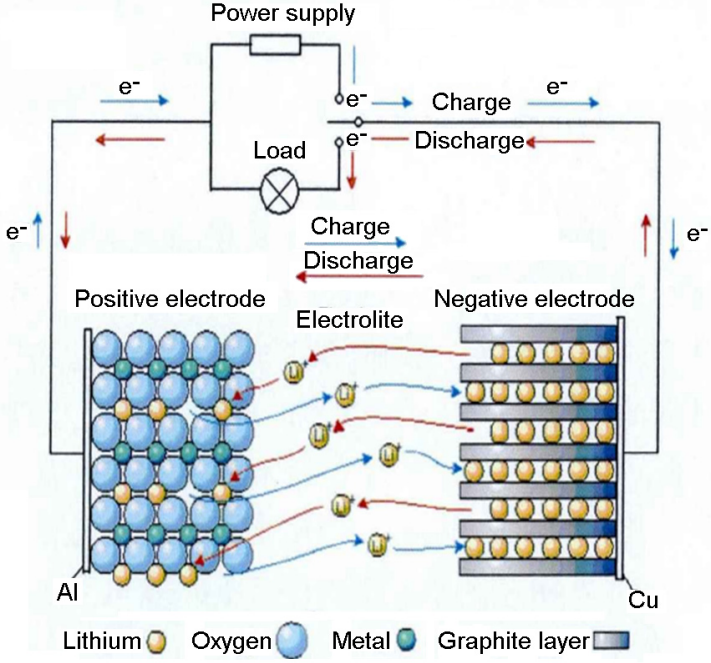

Fig. 2. Lithium - ion battery work diagram

the discharge, the negative electrode will lose an electron through the diaphragm to the positive direction of migration and into the cathode material, while the electronic migration from the external circuit to the cathode material, to achieve energy conversion and storage.

$\mathrm{LiNb}_{3} \mathrm{O}_{8}$ has a monoclinic structure with a space group of P121 / a, which consists of four $\mathrm{Li}$ atoms, $32 \mathrm{O}$ atoms and $12 \mathrm{Nb}$ atoms to form one unit. Its structure consists of twisted $\mathrm{Nb}-\mathrm{O}$ octahedral, Li atoms in the octahedral gap position, as shown in Figure 1. Lithium-ion battery from the positive, negative, electrolyte, diaphragm and current collector and other components. The process of charging and discharging is achieved by the insertion and removal of lithium ions in the positive and negative materials. When the lithium ion is separated from the positive electrode material, it moves from the diaphragm to the negative direction, and the electrons are removed from the positive electrode, migrated from the external circuit to the negative electrode, and an electron is obtained on the negative electrode and then converted into a layered structure In the discharge, the negative electrode will lose an electron through the diaphragm to the positive direction of migration and into the cathode material, while electrons from the same external migration to the cathode material to achieve energy conversion and storage. Figure 2 shows the lithiumion battery work diagram.

2.2 Electrochemical performance of $\mathrm{LiNb}_{3} \mathrm{O}_{8}$ nanocomposites prepared by high energy ball milling

The ease of Lithium ion flow in the electrode material is an important indicator of the performance of the rechargeable battery. In order to improve the electronic contact of the material 
and reduce the surface resistance of the material, the transmission path is provided for the electrons. At the same time, in order to shorten the Li diffusion distance, $\mathrm{LiNb}_{3} \mathrm{O}_{8}$ wide bandgap semiconductor material prepared at $800{ }^{\circ} \mathrm{C}$ is mixed with acetylene black to reduce the particle size, And acetylene black sodium microcomposites, the formation of ions and electrons mixed conductive network. Among them, the high-energy ball mill method is a mechanical method, the nano-materials in the role of mechanical energy refinement, while improving the dispersion of the material. And the product was mixed with acetylene black (mass ratio of 7:2), using a planetary ball mill PM100 for high energy ball milling. The mixture was calcined at $80{ }^{\circ} \mathrm{C}$ for $6 \mathrm{~h}$ in a vacuum oven at a rate of $400 \mathrm{r} / \mathrm{min}$ for a period of time using ethanol as a medium to obtain a composite of $\mathrm{LiNb}_{3} \mathrm{O}_{8}$ and acetylene black.

In order to improve the electronic contact of the material, reduce the surface resistance of the material, providing a transmission path for the electrons. At the same time, in order to shorten the $\mathrm{Li}$ diffusion distance, the $\mathrm{LiNb}_{3} \mathrm{O}_{8}$ wide bandgap semiconductor material prepared at $800^{\circ} \mathrm{C}$ was mixed with acetylene black to reduce the size of the particles, and the sodium microcomposites of $\mathrm{LiNb}_{3} \mathrm{O}_{8}$ and acetylene black were prepared to form a mixed conductive network of ions and electrons. Among them, the high-energy ball mill method is a mechanical method, the nano-materials in the role of mechanical energy refinement, while improving the dispersion of the material. And the product was mixed with acetylene black (mass ratio of 7: 2), using a planetary ball mill PM100 for high energy ball milling. The mixture was dried at $80^{\circ} \mathrm{C}$ for $6 \mathrm{~h}$ in a vacuum oven at a rate of $400 \mathrm{r} / \mathrm{min}$ for a period of time using ethanol as a medium to obtain a composite of $\mathrm{LiNb}_{3} \mathrm{O}_{8}$ and acetylene black. In the sample $4 \mathrm{~h}$, the LiNb3O8 particles began to become smaller, but most of the particles remained unchanged. After 8 hours, the particles were not milled, and some particles remained. after $16 \mathrm{~h}$. There was almost no large particles after ball milling. After milling the sample, there is no change in the phase structure. As the milling time increases, the size of the particles decrease. After 24 hours of ball mill samples, the magnification of the scanning electron microscope magnification, we found that the particles have been nano-sized, reduced by the original $500 \mathrm{~nm}$ to $70 \mathrm{~nm}$ about. This can also be observed from the image of the transmission electron microscope. $\mathrm{LiNb}_{3} \mathrm{O}_{8}$ particles and acetylene black mixed sentence, forming a network composite structure, and there is a certain pore, the electrolyte can be better infiltration.
The nanocomposite materials after ball milling have been greatly improved compared to the electrochemical properties of the original electrode materials. This is mainly due to the fact that the ball mill not only reduces the particle size, but also reduces the diffusion path. At the same time, the ball mill will mix with the acetylene black very uniform, forming a mixed conductive network of ions and electrons, and forming a pore between the particles and the particles Structure, making the electrolyte more easily infiltrated. After the grinding of the $\mathrm{LiNb}_{3} \mathrm{O}_{8}$ material for several weeks, the capacity of the $\mathrm{LiNb}_{3} \mathrm{O}_{8}$ is almost no longer attenuated, possibly due to the absence of the SEI film on its surface. In the voltage range of 1.0-3.0 V, the capacity increased from $120 \mathrm{mAh} / \mathrm{g}$ to $150 \mathrm{mAh} / \mathrm{g}$ after 50 weeks at 0.05 times, and the capacity increased from $30 \mathrm{mAh} / \mathrm{g}$ to $150 \mathrm{mAh} / \mathrm{g}$ after 50 weeks. The discharge capacity of $\mathrm{LiNb}_{3} \mathrm{O}_{8}$ nanocomposites is 212 and $351 \mathrm{mAh} / \mathrm{g}$, respectively, which corresponds to 3.3 reversibly disengaged from $\mathrm{LiNb}_{3} \mathrm{O}_{8}$, indicating that the nanocomposites achieve partial two electron transfer. At the same time, the formation of $\mathrm{LiNb}_{3} \mathrm{O}_{8}$ material can be avoided during the discharge process.

\subsection{Structure and Electrochemical Proper-} ties of LiNb3O8 Nanoparticles

$\mathrm{LiNb}_{3} \mathrm{O}_{8}$ nanocomposites were prepared by high energy ball milling method. The electrochemical performance of $\mathrm{LiNb}_{3} \mathrm{O}_{8}$ nanocomposites was good, and the capacity remained at $180 \mathrm{mAh} / \mathrm{g}$ after 50 cycles. The coulombic efficiency of the first week was only $60.06 \%$. The samples prepared with $\mathrm{Nb}(\mathrm{OH})_{5}$ and $\mathrm{LiOH}$ as precursors were prepared by sol-gel method. The particles were about $70 \mathrm{~nm}$ in size, discharge capacity up to $273 \mathrm{mAh} / \mathrm{g}$ in the first week, and the charge capacity up to $232 \mathrm{mAh} / \mathrm{g}$, the coulombic efficiency to $85 \%$. The first week after charge-discharge, $\mathrm{LiNb}_{3} \mathrm{O}_{8}$ into $\mathrm{Li}_{x} \mathrm{Nb3O}$, is irreversible phase transition.

\section{Energy storage system to assist the renewable energy consumption model.}

\subsection{Energy storage configuration}

Reasonable optimization of energy storage configuration can effectively smooth the distributed power output, reduce its randomness and volatility on the impact of the power grid to improve the utilization of renewable energy. At low load, the energy storage system stores the energy emitted by distributed energy sources such as wind turbines and solar energy and is released at peak load to reduce the power fluctuation of the load. As the load peak and valley 
duration is very short, so the load in the vicinity of the valley, the use of a small amount of energy storage charge, you can significantly uplift trough load, so that the grid to accept more capacity of new energy; but when the load valley To a certain extent, due to its duration gradually longer, energy storage system will consume a significant increase in energy storage capacity. The system is mainly to enhance the power supply system reliability and operational economy, the load on the grid load shedding. Therefore, there is an optimal energy storage system capacity configuration, so that the price cost and economic benefits to achieve the best economic balance. Energy storage device capacity configuration is reasonable, a great impact on the economic operation of the power grid. If the capacity selection is too small, then the wind turbine or photovoltaic cells issued by the excess power cannot be fully stored, resulting in energy waste; if the capacity of choice is too large, will make the system energy storage device is full of long-term and difficult to release. This will greatly reduce the life of the energy storage device and energy conversion efficiency, but also increase the cost of the system.

The new negative material battery is involved in energy storage, energy density is high, safe and reliable, stable performance, but its response speed is difficult to achieve the complex and frequent power fluctuations in the grid to stabilize. Super capacitor has a high response speed, but the high cost, low energy density, large use in the grid will cause the construction cost is too high. If you want to have the response speed and high energy density of the energy storage device, the battery and the super capacitor combined to form a new energy storage device, the hybrid energy storage system at the DC end of the super capacitor and battery through DC-DC conversion Connected to the device can be flexible control of the energy storage battery charge and discharge, the use of the controller to coordinate the two energy storage battery power distribution, improve the utilization of supercapacitors. Through the battery and the super capacitor to complement each other to improve the large-scale renewable energy and network.

\subsection{The objective function}

The introduction of energy storage is conducive to load shifting. It can reduce the system demand for thermal power reserve services and coal consumption of power generation system. The target function is the minimum system power consumption, so as to research the electric energy storage system model. Specific objective function is:

$$
\min F=\sum_{t=1}^{T}\left\{\sum_{i=1}^{I}\left[u_{i t} f\left(g_{i t}\right)+u_{i t}\left(1-u_{i, t-1}\right) N_{i t}\right]\right\}
$$

where $f\left(g_{i t}\right)$ is the electricity energy consumption cost of unit i at time t; $N_{i t}$ is the cost of power generation start stop system; T is the scheduling period, $\mathrm{T}=24 \mathrm{~h} ; u_{i t}$ is generator state, 1 mains the unit is called, 0 mains the unit is not called; $C_{k t}^{I L}$ is the cost of the system calls the interruptible load contract k at time t; $N_{I L}$ is contract number of interruptible load that the system called.

\subsection{The constraint}

Energy storage system is introduced to take the generation side and user side into account. There is a certain effect on the system load demand and power supply structure. The system operation constraints will have a certain change. Specific constraints are as follows:

(1) Load balance of supply and demand constraint

$$
\sum_{i=1}^{I} u_{i t} Q_{i t}+\sum_{k}^{K} Q_{k t}+Q_{s, t}^{-}=D(t)+Q_{s, t}^{+}
$$

(2) Thermal power unit output constraint

$$
\text { s.t. (3) - (5), (7) - (12). }
$$

(3) Energy storage system output constraint

The process of charge and discharge of the energy storage system is affected by the energy storage system of charge and discharge power and storage capacity of the system:

$$
Q_{s, t}=Q_{s, t-1}+Q_{s, t}^{+}-Q_{s, t}^{-} /\left(1-\theta_{s}\right)
$$

where, $\boldsymbol{Q}_{s, t}$ is the storage of electricity in energy system at time; $Q_{s, t}^{+}$is the charging amount of energy storage system at time t; $\boldsymbol{Q}_{s, t}^{-}$is the discharge quantity of energy storage system at time $\mathrm{t} ; \theta_{s}$ is charge and discharge power loss coefficient of energy storage system.

$$
\begin{gathered}
Q_{s, t}^{+} \leq \overline{Q_{s}} \\
Q_{s, t}^{-} \leq \overline{Q_{s}} \\
Q_{s, t}<Q_{s}^{\max }
\end{gathered}
$$

where, $Q_{s}^{\max }$ is the maximum storage capacity of energy storage system; $\overline{Q_{s}}$ is the limit of charge and discharge of energy storage system.

Because the energy storage system would produce a certain loss in the process of charge and discharge, so the cumulative charge quantity and discharge power should satisfy the following constraint condition:

$$
\sum_{t=1}^{T} \boldsymbol{Q}_{s, t}^{+}\left(\mathbf{1}-\theta_{s}\right)=\sum_{t=1}^{T} \boldsymbol{Q}_{s, t}^{-}
$$

If the energy storage system was profitable, the price of energy storage system of charge and discharge need meet the follow constraint:

$$
p_{s, \text { char }}>p_{s, \text { disc }} /\left(1-\theta_{s}\right)
$$

$p_{s, c h a r}$ and $p_{s, \text { disc }}$ are charging price and discharging price of energy storage system. 
Table 2. Operating parameters in thermal power

\begin{tabular}{|c|c|c|c|c|c|c|c|c|c|c|}
\hline Unit & $a_{i}$ & $b_{i}$ & $c_{i}$ & $\begin{array}{c}M_{i}^{\text {on }} \\
/ \mathrm{h}\end{array}$ & $\begin{array}{c}M_{i}^{\text {off }} \\
/ \mathrm{h}\end{array}$ & $\begin{array}{c}N_{i} \\
/ \mathrm{tce}\end{array}$ & $\begin{array}{c}g_{i}^{\text {min }} \\
/ \mathrm{MW}\end{array}$ & $\begin{array}{c}g_{i}^{\max } \\
/ \mathrm{MW}\end{array}$ & $\begin{array}{c}\Delta g_{i}^{+} \\
/ \mathrm{MW} \cdot \mathrm{h}\end{array}$ & $\begin{array}{c}\Delta g_{i}^{-} \\
/ \mathrm{MW} \cdot \mathrm{h}\end{array}$ \\
\hline G1 & 11.6 & 0.260 & $1.88 \mathrm{E}-05$ & 8 & 8 & 25.6 & 250 & 600 & 280 & -280 \\
\hline G2 & 9.7 & 0.259 & $6.55 \mathrm{E}-06$ & 8 & 8 & 23.1 & 200 & 500 & 240 & -240 \\
\hline G3 & 8.8 & 0.268 & $9.44 \mathrm{E}-06$ & 7 & 7 & 22.3 & 200 & 450 & 210 & -210 \\
\hline G4 & 8.4 & 0.273 & $1.65 \mathrm{E}-05$ & 7 & 7 & 19.6 & 180 & 400 & 180 & -180 \\
\hline G5 & 7.2 & 0.28 & $2.17 \mathrm{E}-05$ & 6 & 6 & 16.2 & 150 & 350 & 150 & -150 \\
\hline G6 & 6.1 & 0.285 & $3.39 \mathrm{E}-05$ & 5 & 5 & 15.4 & 150 & 300 & 150 & -150 \\
\hline G7 & 5.2 & 0.292 & $3.42 \mathrm{E}-05$ & 4 & 4 & 12.3 & 120 & 300 & 120 & -120 \\
\hline G8 & 4.6 & 0.304 & $4.13 \mathrm{E}-05$ & 4 & 4 & 8.1 & 100 & 250 & 100 & -100 \\
\hline G9 & 3.5 & 0.306 & $3.63 \mathrm{E}-05$ & 3 & 3 & 4.3 & 70 & 150 & 70 & -70 \\
\hline G10 & 1.4 & 0.314 & $8.35 \mathrm{E}-05$ & 2 & 2 & 2.1 & 30 & 100 & 50 & -50 \\
\hline
\end{tabular}

Table 3. Typical daily load demand and stochastic power output

\begin{tabular}{|c|c|c|c|c|c|c|c||}
\hline \multirow{2}{*}{ Time } & \multirow{2}{*}{ Load Demand/MW } & \multicolumn{2}{|c|}{ Available output/MW } & \multirow{2}{*}{ Time } & Load De- & \multicolumn{2}{|c|}{ Available output/MW } \\
\cline { 7 - 9 } & & $\begin{array}{c}\text { Wind } \\
\text { mand /MW }\end{array}$ & Solar & \multirow{2}{*}{$\begin{array}{c}\text { Wind } \\
\text { Power }\end{array}$} & Solar \\
\hline 1 & 900 & 187 & 0 & 13 & 2500 & 399 & 216 \\
\hline 2 & 1000 & 279 & 0 & 14 & 2300 & 323 & 188 \\
\hline 3 & 1100 & 308 & 0 & 15 & 2100 & 325 & 168 \\
\hline 4 & 1200 & 391 & 0 & 16 & 1800 & 131 & 66 \\
\hline 5 & 1500 & 350 & 0 & 17 & 1700 & 11 & 6 \\
\hline 6 & 1700 & 359 & 209 & 18 & 1900 & 33 & 21 \\
\hline 7 & 1900 & 450 & 240 & 19 & 2100 & 45 & 0 \\
\hline 8 & 2100 & 420 & 262 & 20 & 2500 & 21 & 0 \\
\hline 9 & 2300 & 343 & 194 & 21 & 2300 & 5 & 0 \\
\hline 10 & 2500 & 245 & 146 & 22 & 1900 & 220 & 0 \\
\hline 11 & 2600 & 442 & 221 & 23 & 1300 & 294 & 0 \\
\hline 12 & 2700 & 369 & 209 & 24 & 1000 & 249 & 0 \\
\hline
\end{tabular}

Table 4. Optimal results of power system under different scenarios

\begin{tabular}{|c|c|c|c|c|c|c|c|c|}
\hline \multirow{2}{*}{ Scene } & \multicolumn{3}{|c|}{ Wind power } & \multicolumn{3}{c|}{ Solar power } & \multicolumn{2}{c|}{ Thermal power } \\
\cline { 2 - 9 } & $\begin{array}{c}\text { Generating } \\
\text { capacity } \\
(\mathrm{MWh})\end{array}$ & $\begin{array}{c}\text { Grid } \\
\text { percent } \\
(\%)\end{array}$ & $\begin{array}{c}\text { Abandoned } \\
\text { wind rate } \\
(\%)\end{array}$ & $\begin{array}{c}\text { Generating } \\
\text { capacity } \\
(\mathrm{MWh})\end{array}$ & $\begin{array}{c}\text { Grid } \\
\text { percent } \\
(\%)\end{array}$ & $\begin{array}{c}\text { Abandoned } \\
\text { wind } \\
\text { rate (\%) }\end{array}$ & $\begin{array}{c}\text { Generating } \\
\text { capacity } \\
\text { (MWh) }\end{array}$ & $\begin{array}{c}\text { Grid } \\
\text { percent } \\
(\%)\end{array}$ \\
\hline Origin & 5618 & 10.20 & 11.2 & 2032 & 3.69 & 8.4 & 47415 & 86.11 \\
\hline Sce.1 & 5659 & 10.28 & 9.47 & 2041 & 3.71 & 6.79 & 47364 & 86.02 \\
\hline Sce.2 & 5683 & 10.32 & 8.92 & 1997 & 3.63 & 6.97 & 47385 & 86.05 \\
\hline
\end{tabular}

\section{Calculation example}

\subsection{Basic data}

This section selects thermal power units in table 1 to access into the wind power and solar power generation unit, installed capacity of which are $650 \mathrm{MW}$ and $250 \mathrm{MW}$, so a simulation system has formed. Assuming the intervention of energy storage system is $400 \mathrm{MW}$, the maxi- mum charge and discharge power is $80 \mathrm{MW}$. Additionally, wind power tariff in system is 510 Yuan/MW $\cdot \mathrm{h}$; The average power consumption of large users of each period is $520 \mathrm{MW} \cdot \mathrm{h}$; Energy consumption volatility of adjacent time period is $\pm 260 \mathrm{MW} \cdot \mathrm{h}$; Benchmark price of thermal power is 350 Yuan/MW $\cdot h$. Table 2 shows that operating parameters in thermal power Available power output of wind and solar in Table 3 
is involved in the scheduling system as the output of random power. This paper uses software of GAMs to solve model, so power resources optimization results could be obtained in different ways. Table 3 shows that typical daily load demand and stochastic power output.

\subsection{Power resource optimization result by} assistance of energy storage system

Assuming the loss factor of discharge conversion in energy storage system is $15 \%$; Charge and discharge prices of energy storage system are assumed to be $330 \mathrm{Yuan} / \mathrm{MW} \cdot \mathrm{h}, 500 \mathrm{Yuan} /$ $\mathrm{MW} \cdot \mathrm{h}$; Fixed cost is 180,000 Yuan. In order to analyze the promotion of energy storage system on wind power consumption, this paper makes optimization on three scenarios which capacity are 0MW, 200MW and 400MW. Optimization results of different scenarios are shown in Table 4.

Through the contrast of optimization results in different scenarios, abandoned wind and light rates are shown a downward trend with the access and expansion of energy storage system, unit utilization efficiency is also gradually improved. In the scenario without energy storage system, abandoned wind and light rates are $11.2 \%$ and $8.4 \%$, After introducing energy storage system, abandoned wind and light rates are $9.47 \%$ and $6.79 \%$.

In power structure, we can see grid electricity of thermal power showed a decreasing trend with the increase of randomness power. Coal consumption rate of thermal power is 344.6 $\mathrm{kg} / \mathrm{MWh}$ in absence of energy storage system. When introducing energy storage system with 200MW, coal consumption rate is 344.3 $\mathrm{kg} / \mathrm{MWh}$, with the reduction of $0.3 \mathrm{~kg} / \mathrm{MWh}$. When introducing the energy storage system with 400MW coal consumption rate is $343.5 \mathrm{~kg} /$ MWh, with the reduction of $1.1 \mathrm{~kg} / \mathrm{MWh}$.

\section{Conclusions}

This paper presents the use of new battery anode materials to participate in energy storage, and build energy storage system, and then analyze the energy storage system energy consumption patterns and related models, and finally through the example of the feasibility of the project, economic feasibility. The results show that the energy storage system can enhance the ability of eliminating random power and reduce the starting and stopping of thermal power units, so as to optimize the utilization of electric power resources.

Acknowledgements. Project Supported by National Natural Science Foundation of China (71573084) and Beijing Municipal Social Science Foundation(16JDYJB044)

\section{References}

1. Wang Chenshan, Wu Zhen, Li Peng, Automat. Electr. Power Syst., 38(16), 1, 2014.

2. Wang Sibo, Wei Tongzhen, Qi Zhiping, Proceedings of the CSEE, 30 (9), 105, 2010.

3. Dai Xingjian, Deng Zhanfeng, Liu Gang, et al. Trans.China Electrotechn. Soc., 26 (7), 133, 2011.

4. Zhang Qun, Mao Chengxiong, Xie Junwin, et al., Proceedings of the CSEE, 32(25), 79, 2012.

5. Bao Guannan, et al. Automat.Electric Syst., 36(12), 11, 2014.

6. Li Junhui, Research on the Optimal Plan and Control of Energy Storage System to Reduce the Effect of Wind Power on the Grid [D]. North China Electric Power University, 2012

7. You Yi, et al. Automat. Electr. Power Syst., 38 (18), 46, 2014. 